\title{
Investigation on Anti-Inflammatory and Antiulcer Activities of Anchusa azurea Extracts and their Major Constituent Rosmarinic Acid
}

Ayse Kuruuzum-Uz ${ }^{\mathrm{a}}$, Halis Suleyman ${ }^{\mathrm{b}}$, Elif Cadircic,*, Zuhal Guvenalp ${ }^{\mathrm{d}}$, and L. Omur Demirezer ${ }^{a}$

a Department of Pharmacognosy, Faculty of Pharmacy, Hacettepe University, 06100 Ankara, Turkey

b Department of Pharmacology, Faculty of Medicine, Ataturk University, 25240 Erzurum, Turkey

c Department of Pharmacology, Faculty of Pharmacy, Ataturk University, 25240 Erzurum, Turkey. Fax: +90 442 2360968. E-mail: ecadirci@atauni.edu.tr

d Department of Pharmacognosy, Faculty of Pharmacy, Ataturk University, 25240 Erzurum, Turkey

* Author for correspondence and reprint requests

Z. Naturforsch. 67 c, 360-366 (2012); received March 13, 2011/April 11, 2012

This study investigated the anti-inflammatory and antiulcer activities of different extracts from the aerial parts and the roots of Anchusa azurea Miller var. azurea (Boraginaceae), as well as their major constituent, rosmarinic acid. The extracts were water (AWa, RWa) and methanol (AMe, RMe) extracts prepared from the aerial parts and the roots of $A$. azurea, respectively. The AMe extract was found to exert anti-inflammatory effects; so it was evaporated to dryness and the residue was dissolved in distilled water (AMeWa) and then further fractionated with $n$-hexane (AMeHe) and $n$-butanol (AMeBu). Anti-inflammatory activity was investigated in rats using carrageenan-induced acute inflammation, and antiulcer activity was investigated using indomethacin-induced gastric damage. The methanolic extract from the aerial parts, its $n$-butanol fraction, and rosmarinic acid, which was isolated from the $n$-butanol fraction of the AMe extract, showed significant dose-dependent antiinflammatory activity. During the acute phase of inflammation, the anti-inflammatory activity of rosmarinic acid was comparable to that of ibuprofen. No antiulcer activity was observed. The experimental data demonstrate that A. azurea Miller var. azurea and rosmarinic acid display significant anti-inflammatory activity.

Key words: Anti-Inflammatory, Anchusa azurea, Rosmarinic Acid

\section{Introduction}

There are fifteen species of the genus Anchu$s a$ L. (Boraginaceae) found among the flora of Turkey (Chamberlain, 1978). Several species of Anchusa are used in folk medicine for treating open wounds and cuts (Dafni et al., 1984; Lardos, 2006), rheumatism, arthritis, gout (Ali-Shtayeh et al., 2000; El Beyrouthy et al., 2009), stomach diseases, and weight loss (Al-Qura'n, 2009). In other instances, Anchusa is used as a diuretic agent (Baytop, 1984). Antibacterial and antifungal activity (Nader et al., 1986) and the inhibition of aryl hydrocarbon hydroxylase activity (Alwan et al., 1990) have also been reported in a study examining A. strigosa. An ointment prepared from a decoction of $A$. azurea Miller roots mixed with egg yolk and beeswax is used externally for wound healing (Honda et al., 1996). The dried and powdered leaves are used externally as a desiccant for wounds (Yesilada et al., 1995). Radical scavenging and iron-chelating activities of $A$. azurea have also been reported (El and Karakaya, 2004). In Jordan and Palestine, practitioners of folk medicine use the hot aqueous extracts of $A$. strigosa roots in the treatment of stomach ulcers. It was reported that these roots have both a protective and a treatment effect on ethanol-induced ulcers in rats and guinea pigs (Disi et al., 1998). In another study, both the ethanol and aqueous extracts of A. azurea were found to be ineffective in anti-inflammatory and antinociceptive activity tests (Kupeli et al., 2007). Pyrrolizidine alkaloids, flavonoids, triterpene saponins, fatty acids, and phenolic acids have been isolated from this species (Demirezer and Zeeck, 2000; Guil-Guerrero 
et al., 2001; Erdemoglu et al., 2004; Kuruuzum-Uz et al., 2010).

Inflammatory diseases and ulcers are one of the world's major health problems. In inflammatory diseases, non-steroidal anti-inflammatory drugs are used as the first choice of treatment; however, their usage is limited because of the ulcerogenic side effects that they exert on the gastrointestinal system (Suleyman et al., 2008). In recent studies, investigators have sought to develop or discover new herbal drugs with anti-inflammatory effects and no ulcerogenic effects. Determining a compound that simultaneously demonstrates both anti-inflammatory and antiulcerogenic effects would represent significant development in ulcer and inflammation treatment (Albayrak et al., 2010). Recent studies have focused more attention on herbal drugs (Cadirci et al., 2007). Many experimental animal studies have demonstrated that plant extracts have lower toxicities than synthetic drugs (Suleyman et al., 1999; Odabasoglu et al., 2006). This is one of herbal drugs' most important advantages. Also, the wound-healing effect that the Anchusa species are reported to have is related to inflammation and ulcerogenic disorders. In our previous study on the aerial parts of $A$. azurea, phenolic acids, flavonoid glycosides, and triterpene glycosides were isolated, and the results of this study showed that $A$. azurea contains a very high concentration of rosmarinic acid (Kuruuzum-Uz et al., 2010). In order to evaluate the ethnobotanical information on Anchusa, water extracts used to form traditional medicines and various extracts, as well as rosmarinic acid, from $A$. azurea Miller var. azurea were investigated to determine their anti-inflammatory and antiulcer activities in experimental rat models.

\section{Material and Methods}

\section{Plant material and preparation of extracts}

Anchusa azurea Miller var. azurea was collected from Ankara-Beytepe on July 15, 2003 and identified by Dr. Hayri Duman of the Department of Biology Gazi University, Ankara, Turkey. Under the number HUEF 03012, a voucher specimen was deposited at the herbarium of Hacettepe University, Faculty of Pharmacy, Ankara, Turkey.

The extracts used in this study were water (AWa, RWa) and methanol extracts (AMe, RMe) prepared from the aerial parts and roots of $A$. azurea, respectively. Secondly, the methanol ex- tract of the aerial parts, which exerted good antiinflammatory activity, was dissolved in distilled water (AMeWa) and then further fractionated with $n$-hexane (AMeHe) and $n$-butanol (AMe$\mathrm{Bu})$ to give the respective extracts.

Air-dried and powdered aerial parts of the plant $(600 \mathrm{~g})$ were extracted three times with $3 \mathrm{~L}$ methanol under reflux for $3 \mathrm{~h}$ at $45^{\circ} \mathrm{C}$. The total filtrate was concentrated under reduced pressure to yield the methanol extract (AMe, $78 \mathrm{~g}$, yield $13 \%$ ). The methanol extract was dissolved in distilled water $(150 \mathrm{~mL})$ and partitioned with $n$-hexane (AMeHe, $10.4 \mathrm{~g}$, yield $1.73 \%$ ) and $n$-butanol (AMeBu, $7 \mathrm{~g}$, yield $1.17 \%$ ). The remaining aqueous layer was concentrated and then lyophilized (AMeWa, $15 \mathrm{~g}$, yield 2.50\%). Air-dried and powdered roots of the plant $(480 \mathrm{~g})$ were also extracted with methanol ( $5 \times 1.5 \mathrm{~L})$ under reflux for $3 \mathrm{~h}$ at $45^{\circ} \mathrm{C}$, and the filtrate was evaporated under reduced pressure (RMe, $22 \mathrm{~g}$, yield $4.58 \%$ ). In addition, aerial parts $(100 \mathrm{~g})$ and roots $(100 \mathrm{~g})$ were separately extracted with distilled water $(2 \mathrm{x}$ $1 \mathrm{~L}$ ) at $45{ }^{\circ} \mathrm{C}$ during $2 \mathrm{~h}$ and filtered. Both of the filtrates were concentrated and then lyophilized (AWa, $11 \mathrm{~g}$, yield 11\%; RWa, $13 \mathrm{~g}$, yield 13\%).

\section{Isolation of rosmarinic acid $(R A)$}

The $n$-butanol extract prepared from the methanolic extract of the aerial parts of $A$. azurea was dissolved in methanol $(\mathrm{MeOH})$ and then subjected to gel filtration over Sephadex LH 20 (Fluka, Steinheim, Germany) (200 g) with $\mathrm{MeOH}$ as eluant (100-mL fractions). Each fraction was monitored by TLC, and fractions with similar TLC patterns were collected to afford five main fractions (A-E): (A) fractions 1-10, $3.5 \mathrm{~g}$; (B) fractions 11-14, $0.7 \mathrm{~g}$; (C) fractions $15-25,1.2 \mathrm{~g}$; (D) fractions 26-28, $1.0 \mathrm{~g}$; (E) fractions $29-32,0.3 \mathrm{~g}$. Fraction D was applied to a Sephadex LH $20(40 \mathrm{~g})$ column using $\mathrm{MeOH}$ as eluant. Fractions of $15 \mathrm{~mL}$ each were collected (D1-D37). Fractions D1-D26 were combined to give pure rosmarinic acid $(150 \mathrm{mg})$, and fractions D27-D37 $(870 \mathrm{mg})$ were combined and applied to further column chromatography over silica gel eluting with $\mathrm{CHCl}_{3} / \mathrm{MeOH} / \mathrm{H}_{2} \mathrm{O}(80: 20: 2 \mathrm{v} / \mathrm{v} / \mathrm{v}$, $150 \mathrm{~mL}$ and $70: 30: 3 \mathrm{v} / \mathrm{v} / \mathrm{v}, 200 \mathrm{~mL}$ ) and $\mathrm{MeOH}$ $(100 \mathrm{~mL})$. After this process, subfractions of D27-D37 were subjected repeatedly to Sephadex LH-20 column chromatography for obtaining more pure rosmarinic acid $(350 \mathrm{mg})$. Rosmarinic 
acid was identified by comparing its NMR and mass data with those given in the literature (Kelley et al., 1976). ${ }^{1} \mathrm{H}$ and ${ }^{13} \mathrm{C}$ NMR spectra were recorded on Varian (Palo Alto, CA, USA) Mercury plus $400 \mathrm{MHz}$ (for proton) and $100 \mathrm{MHz}$ (for carbon) instruments in $\mathrm{CD}_{3} \mathrm{OD}$ using tetramethylsilane (TMS) as internal standard. EI mass spectra were recorded on a Finnigan (Waltham, MA, USA) MAT 95 spectrometer.

\section{Animals}

Male Wistar albino rats (185-200 g) were used. They were fed with standard laboratory chow and kept at $22{ }^{\circ} \mathrm{C}$. All animals were obtained from the Experimental Animal Laboratory, Department of Pharmacology, Faculty of Medicine, Ataturk University, Ezurum, Turkey. The experiments were conducted according to the ethical norms approved by the Ethics Committee of Experimental Animal Teaching and Researcher Center (No. B.30.2.ATA.0.70/71). The animals were grouped before the experiments and kept under standard conditions. A minimum of six animals was used in each group.

\section{Chemicals and drugs}

Carrageenan was purchased from SigmaAldrich (Steinheim, Germany). The standard drugs that were used were indomethacin (Deva, Istanbul, Turkey), and ibuprofen and famotidine (Eczacibasi, Istanbul, Turkey). All other chemicals used were of analytical grade and purchased from Merck (Darmstadt, Germany).

\section{Carrageenan-induced paw edema in rats}

In the first series of our experiment, we investigated the anti-inflammatory activity of the primary extracts (water and methanol) of aerial parts and roots of $A$. azurea (AWa, RWa, AMe, $\mathrm{RMe}$ ) using doses of 100 and $200 \mathrm{mg} / \mathrm{kg}$ body weight (bw) to treat carrageenan-induced paw edema in rats (Winter et al., 1962). In this series, we used $25 \mathrm{mg} / \mathrm{kg}$ bw indomethacin as a reference drug. Initially, the rats were divided into 10 groups $(n=6), 9$ of which received RWa, RMe, AWa, AMe (each at 100 and $200 \mathrm{mg} / \mathrm{kg}$ bw), and indomethacin $(25 \mathrm{mg} / \mathrm{kg} \mathrm{bw})$, respectively, by oral gavage. The control group received an equal volume of distilled water as the vehicle. One $h$ after administration of the extracts, $0.1 \mathrm{~mL}$ of $1 \%$ carrageenan was injected into the hind paw of each animal. Before the carrageenan injection, the volume of the normal paw was measured up to the knee joint by plethysmometry. The carrageenan-induced increase in the paw volume (paw edema) was measured four times at 1-h intervals. The anti-inflammatory effects of the drugs were determined by comparing the results of the drugtreated groups with those of the control group. The percentages of the anti-inflammatory activities of the RWa, RMe, AWa, AMe extracts, and control drug (indomethacin) were calculated using the following formula: \% inhibition $=(1-$ $\left.D_{\mathrm{t}} / D_{0}\right) \cdot 100$, where $D_{0}$ is the average inflammation of the control group of rats at a given time and $D_{\mathrm{t}}$ is the average inflammation of the drugtreated (i.e. extracts or reference indomethacin) rats at the same time.

In the second series of our experiments, we investigated the anti-inflammatory activity of different fractions of the AMe extract (AMeHe, $\mathrm{AMeWa}$ and $\mathrm{AMeBu}$ ) and the reference drug indomethacin using the same model. The reason why we studied the fractions of AMe is that it was the most effective extract in the first experiment. The rats were divided into 8 groups. Each group consisted of six animals. There were 7 groups of rats that received $\mathrm{RWa}, \mathrm{RMe}, \mathrm{AWa}, \mathrm{AMe}$ (each at 100 and $200 \mathrm{mg} / \mathrm{kg} \mathrm{bw}$ ), and indomethacin ( $25 \mathrm{mg} / \mathrm{kg}$ bw), respectively, by oral gavage. The control group received an equal volume of distilled water as vehicle. In the second series of experiments, the AMeBu extract exerted the highest anti-inflammatory effects; so, in the last series of the anti-inflammatory activity experiments, we investigated the anti-inflammatory effects of rosmarinic acid isolated as a major component from the $\mathrm{AMeBu}$ extract. For this series, we selected 7 groups of rats; each group consisted of six animals. The doses of rosmarinic acid, as well as of ibuprofen, both administered by oral gavage, were 10,25 , and $50 \mathrm{mg} / \mathrm{kg}$ bw. The last group received an equal volume of distilled water as vehicle. The anti-inflammatory effects of the extracts were determined as described above.

\section{Indomethacin-induced gastric damage in rats}

In this series of experiments, the effects of the prepared extracts on the indomethacin-induced gastric damage were analysed. Male Wistar rats fasted for $24 \mathrm{~h}$ had free access to water and were, 
respectively, treated with the extracts and famotidine $(20 \mathrm{mg} / \mathrm{kg}$ bw) by oral gavage. After $5 \mathrm{~min}$ of oral treatment, indomethacin $(25 \mathrm{mg} / \mathrm{kg} \mathrm{bw})$ was administered to all groups of animals, and $6 \mathrm{~h}$ later the animals were sacrificed to evaluate their stomachs for ulcer areas.

\section{Statistical analysis}

Results are presented as mean \pm S.D. Statistical calculations were done using SPSS 13.0 software. Data were analysed using one-way ANOVA with post-hoc LSD test. The level of statistical significance was defined to be $p<0.05$.

\section{Results and Discussion}

In the present study, the anti-inflammatory and antiulcer activities related to the woundhealing activity of the extracts from the aerial parts and roots of $A$. azurea Miller var. azurea (Boraginaceae) have been investigated. In addition, rosmarinic acid, isolated as the major constituent from the methanolic extract of the aerial parts of $A$. azurea and its $n$-butanol fraction, was found to exhibit significant anti-inflammatory activity. The effects of the extracts and rosmarinic acid on acute carrageenan-induced inflammation and indomethacin-induced gastric damage in rats were investigated as well. As a result of the serial chromatographic separations, rosmarinic acid was isolated and its structure elucidated based on spectroscopic data (UV, IR, ${ }^{1} \mathrm{H}$ NMR, ${ }^{13} \mathrm{C}$ NMR, COSY, HMQC, HMBC, and EIMS) and compared with previously reported data (Kelley et al., 1976) (Fig. 1)

The results of the initial anti-inflammatory activity assay indicated that the methanol extract of aerial parts (AMe) exhibited anti-inflammatory activity (30\% at a dose of $200 \mathrm{mg} / \mathrm{kg}$ bw, Table I). So we fractionated the AMe extract to its water,

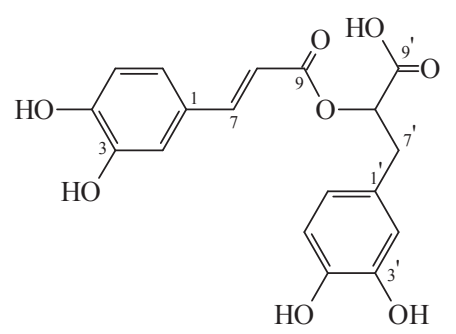

Fig. 1. Chemical structure of rosmarinic acid. $n$-hexane, and $n$-butanol extracts. In the second experiment, only the $\mathrm{AMeBu}$ fraction, of all $\mathrm{AMe}$ fractions, exerted significant anti-inflammatory activity ( $42 \%$ at a dose of $200 \mathrm{mg} / \mathrm{kg}$ bw, Table II). The contents of the major compound rosmarinic acid in the AMe and $\mathrm{AMeBu}$ fractions were found to be 1.28 and $14.2 \%$, respectively. So we isolated rosmarinic acid from the $\mathrm{AMeBu}$ extract and evaluated its anti-inflammatory effect as well.

The activity of rosmarinic acid at a dose of $50 \mathrm{mg} / \mathrm{kg}$ bw is comparable to that of indomethacin, a well-known prostaglandin synthesis inhibitor, at $25 \mathrm{mg} / \mathrm{kg}$ bw and ibuprofen at $50 \mathrm{mg} / \mathrm{kg}$ bw, (Tables I-III). The anti-inflammatory effects of the $\mathrm{AMe}$ and $\mathrm{AMeBu}$ extracts appear to be related to their rosmarinic acid content. However no antiulcer activity was observed (data not shown).

Acute anti-inflammatory activities of compounds or drugs are generally investigated using an acute aseptic model (paw edema) in which arthritis can be induced by histamine, formalin, dextran, or carrageenan. The carrageenan-induced paw edema is the most widely used primary test for the screening of new anti-inflammatory agents (Winter et al., 1962). The carrageenan-induced inflammatory reaction has two phases: early and late. The sub-plantar injection of carrageenan produces a local edema that increases progressively and reaches its maximum within $3-5 \mathrm{~h}$. It was shown that while the early phase is associated with the release of histamine, serotonin, and bradykinin, the late phase is usually associated with the release of prostaglandin (Ramprasath et al., 2004). In our study, the anti-inflammatory effects of the drugs peaked $3 \mathrm{~h}$ after carrageenan injection. This period is accepted as the late phase of carrageenan-induced inflammation. Reaching the peak level of their anti-inflammatory effect after $3 \mathrm{~h}$ means that they probably inhibit prostaglandin synthesis. Cyclooxygenase (COX), responsible for prostaglandin synthesis, and lipoxygenase also have a role in carrageenan-induced inflammation. Non-selective COX inhibitors such as indomethacin, ibuprofen, and diclofenac sodium inhibit the COX-1 and COX-2 enzymes (Burke et $a l ., 2006)$. Indomethacin and ibuprofen are strong non-steroidal anti-inflammatory drugs (NSAIDs) that exert high anti-inflammatory effects (Burke et al., 2006). In our study, the effects of these two NSAIDs used as reference anti-inflammatory agents and those of the $\mathrm{AMe}$ and, $\mathrm{AMeBu}$ extracts and rosmarinic acid were comparable. 
Table I. Effects of water and methanol extracts from roots (RWa, RMe) and aerial parts (AWa, AMe) of A. azurea and of indomethacin on carrageenan-induced rat paw edema.

\begin{tabular}{|c|c|c|c|c|c|c|}
\hline \multirow[t]{2}{*}{ Extract } & \multirow{2}{*}{$\begin{array}{c}\text { Dose } \\
(\mathrm{mg} / \mathrm{kg})\end{array}$} & \multicolumn{2}{|c|}{ Paw volume $[\mathrm{mL}]$} & \multirow{2}{*}{$\begin{array}{c}\text { Increase in } \\
\text { inflammatory } \\
\text { paw volume } \\
{[\mathrm{mL}]}\end{array}$} & \multirow{2}{*}{$\begin{array}{l}\text { Anti-inflam- } \\
\text { matory effect } \\
(\%)\end{array}$} & \multirow[t]{2}{*}{$p$} \\
\hline & & $\begin{array}{c}\text { Before } \\
\text { inflammation }\end{array}$ & $\begin{array}{l}\text { After } 3 \mathrm{~h} \text { of } \\
\text { inflammation }\end{array}$ & & & \\
\hline RWa & 100 & $0.83 \pm 0.035$ & $1.55 \pm 0.087$ & $0.72 \pm 0.026$ & 3 & $>0.05$ \\
\hline RWa & 200 & $0.87 \pm 0.032$ & $1.52 \pm 0.098$ & $0.65 \pm 0.031$ & 12 & $>0.05$ \\
\hline $\mathrm{RMe}$ & 100 & $0.75 \pm 0.025$ & $1.33 \pm 0.056$ & $0.58 \pm 0.041$ & 6 & $>0.05$ \\
\hline $\mathrm{RMe}$ & 200 & $0.73 \pm 0.041$ & $1.29 \pm 0.12$ & $0.56 \pm 0.036$ & 10 & $>0.05$ \\
\hline AWa & 100 & $0.79 \pm 0.023$ & $1.49 \pm 0.078$ & $0.70 \pm 0.024$ & 5 & $>0.05$ \\
\hline AWa & 200 & $0.79 \pm 0.031$ & $1.47 \pm 0.068$ & $0.68 \pm 0.032$ & 8 & $>0.05$ \\
\hline AMe & 100 & $0.78 \pm 0.028$ & $1.37 \pm 0.074$ & $0.63 \pm 0.13$ & 14 & $>0.05$ \\
\hline $\mathrm{AMe}$ & 200 & $0.80 \pm 0.045$ & $1.28 \pm 0.055$ & $0.52 \pm 0.078$ & 30 & $<0.05$ \\
\hline Indomethacin & 25 & $0.80 \pm 0.03$ & $1.18 \pm 0.047$ & $0.38 \pm 0.015$ & 49 & $<0.05$ \\
\hline Control & - & $0.84 \pm 0.023$ & $1.58 \pm 0.099$ & $0.74 \pm 0.061$ & - & - \\
\hline
\end{tabular}

The results given are means \pm S.D.

Table II. Effects of the $n$-hexane (AMeHe), water (AMeWa), and $n$-butanol (AMeBu) extracts, respectively, prepared from the methanol extract of aerial parts of $A$. azurea and of indomethacin on carrageenan-induced rat paw edema.

\begin{tabular}{|c|c|c|c|c|c|c|}
\hline \multirow[t]{2}{*}{ Extract } & \multirow{2}{*}{$\begin{array}{c}\text { Dose } \\
(\mathrm{mg} / \mathrm{kg})\end{array}$} & \multicolumn{2}{|c|}{ Paw volume [mL] } & \multirow{2}{*}{$\begin{array}{c}\text { Increase in } \\
\text { inflammatory } \\
\text { paw volume } \\
{[\mathrm{mL}]}\end{array}$} & \multirow{2}{*}{$\begin{array}{l}\text { Anti-inflam- } \\
\text { matory effect } \\
\qquad(\%)\end{array}$} & \multirow[t]{2}{*}{$p$} \\
\hline & & $\begin{array}{c}\text { Before } \\
\text { inflammation }\end{array}$ & $\begin{array}{l}\text { After } 3 \mathrm{~h} \text { of } \\
\text { inflammation }\end{array}$ & & & \\
\hline AMeHe & 100 & $0.74 \pm 0.041$ & $1.53 \pm 0.091$ & $0.75 \pm 0.052$ & - & $>0.05$ \\
\hline $\mathrm{AMeHe}$ & 200 & $0.76 \pm 0.024$ & $1.48 \pm 0.112$ & $0.72 \pm 0.046$ & - & $>0.05$ \\
\hline AMeWa & 100 & $0.71 \pm 0.019$ & $1.46 \pm 0.101$ & $0.75 \pm 0.034$ & - & $>0.05$ \\
\hline AMeWa & 200 & $0.80 \pm 0.023$ & $1.48 \pm 0.053$ & $0.68 \pm 0.063$ & 4 & $>0.05$ \\
\hline $\mathrm{AMeBu}$ & 100 & $0.78 \pm 0.037$ & $1.32 \pm 0.074$ & $0.55 \pm 0.073$ & 22 & $>0.05$ \\
\hline $\mathrm{AMeBu}$ & 200 & $0.81 \pm 0.018$ & $1.21 \pm 0.085$ & $0.41 \pm 0.075$ & 42 & $<0.01$ \\
\hline Indomethacin & 25 & $0.78 \pm 0.04$ & $1.16 \pm 0.091$ & $0.38 \pm 0.033$ & 47 & $<0.05$ \\
\hline Control & - & $0.79 \pm 0.025$ & $1.50 \pm 0.065$ & $0.71 \pm 0.048$ & - & - \\
\hline
\end{tabular}

The results given are means \pm S.D.

Table III. Effects of rosmarinic acid (RA) and ibuprofen on carrageenan-induced rat paw edema.

\begin{tabular}{|c|c|c|c|c|c|c|}
\hline \multirow[t]{2}{*}{ Drug } & \multirow{2}{*}{$\begin{array}{c}\text { Dose } \\
(\mathrm{mg} / \mathrm{kg})\end{array}$} & \multicolumn{2}{|c|}{ Paw volume [mL] } & \multirow{2}{*}{$\begin{array}{c}\text { Increase in } \\
\text { inflammatory } \\
\text { paw volume } \\
{[\mathrm{mL}]}\end{array}$} & \multirow{2}{*}{$\begin{array}{l}\text { Anti-inflam- } \\
\text { matory effect } \\
\qquad(\%)\end{array}$} & \multirow[t]{2}{*}{$p$} \\
\hline & & $\begin{array}{c}\text { Before } \\
\text { inflammation }\end{array}$ & $\begin{array}{l}\text { After } 3 \mathrm{~h} \text { of } \\
\text { inflammation }\end{array}$ & & & \\
\hline$\overline{\mathrm{RA}}$ & 10 & $0.79 \pm 0.03$ & $1.32 \pm 0.058$ & $0.53 \pm 0.024$ & 13.2 & $>0.05$ \\
\hline RA & 25 & $0.85 \pm 0.021$ & $1.21 \pm 0.051$ & $0.36 \pm 0.022$ & 40 & $<0.05$ \\
\hline RA & 50 & $0.87 \pm 0.012$ & $1.20 \pm 0.064$ & $0.33 \pm 0.019$ & 45.9 & $<0.05$ \\
\hline Ibuprofen & 10 & $0.82 \pm 0.025$ & $1.36 \pm 0.078$ & $0.54 \pm 0.018$ & 11.5 & $>0.05$ \\
\hline Ibuprofen & 25 & $0.84 \pm 0.031$ & $1.32 \pm 0.066$ & $0.48 \pm 0.041$ & 21.4 & $>0.05$ \\
\hline Ibuprofen & 50 & $0.86 \pm 0.021$ & $1.27 \pm 0.041$ & $0.41 \pm 0.032$ & 32.8 & $<0.05$ \\
\hline Control & - & $0.79 \pm 0.014$ & $1.40 \pm 0.087$ & $0.61 \pm 0.062$ & - & - \\
\hline
\end{tabular}

The results given are means \pm S.D. 
Rosmarinic acid is an important caffeoyl ester (phenolic depside) with proven medicinal properties and well-characterized physiological functions. The most recent studies on rosmarinic acid activity confirmed that caffeoyl esters, such as rosmarinic acid, exhibit the highest specific antioxidant activity, delay vitamin E depletion, and decrease the production of pro-inflammatory lysophosphatidylcholines (Cartron et al., 2001). rosmarinic acid prevents the oxidation of lowdensity lipoproteins and its constituents (vitamin $\mathrm{E}$, phosphatidylcholine), which is compatible with its anti-inflammatory and antiatherosclerotic role in pathophysiological conditions (Cartron et al., 2001). Sanbongi et al. (2004) reported that the oral administration of rosmarinic acid is an effective intervention against allergic asthma, and Youn et al. (2003) demonstrated that rosmarinic acid suppressed synovitis in mice and suggested that it may be beneficial in the treatment of rheumatoid

Al-Qura'n S. (2009), Ethnopharmacological survey of wild medicinal plants in Showbak, Jordan. J. Ethnopharmacol 123, $45-50$.

Albayrak A., Polat B., Cadirci E., Hacimuftuoglu A., Halici Z., Gulapoglu M., Albayrak F., and Suleyman H. (2010), Gastric anti-ulcerative and anti-inflammatory activity of metyrosine in rats. Pharmacol. Rep. 62, 113-119.

Ali-Shtayeh M. S., Yaniv Z., and Mahajna J. (2000), Ethnobotanical survey in the Palestinian area: a classification of the healing potential of medicinal plants. J. Ethnopharmacol. 73, 221-232.

Alwan A. H., Mahmoud M. J., and Naji A. (1990), Effects of plant-extracts on aryl-hydrocarbon hydroxylase-activity and $\mathrm{H}-3$ benzo(a)pyrene binding to DNA. J. Food Safety 10, 209-218.

Baytop T. (1984), Therapy with Medicinal Plants in Turkey (Past and Present). Nobel Tip Kitabevleri, Istanbul.

Burke A., Smyth E., and Fitzgerald G. A. (2006), Analgesic-antipyretic agents; pharmacotherapy of gout. In: Goodman \& Gilman's The Pharmacological Basis of Therapeutics (Brunton L. L., Lazo J. S., and Parker K. L., eds.). McGraw-Hill, New York, pp. 671-715.

Cadirci E., Suleyman H., Aksoy H., Halici Z., Ozgen U., Koc A., and Ozturk N. (2007), Effects of Onosma armeniacum root extract on ethanol-induced oxidative stress in stomach tissue of rats. Chem. Bi. Interact. 170, 40-48.

Cartron E., Carbonneau M. A., Fouret G., Descomps B., and Leger C. L. (2001), Specific antioxidant activity arthritis. Unlike antihistamines, rosmarinic acid prevents the activation of immune responder cells that cause swelling and fluid formation. All these data support our conclusion that rosmarinic acid is likely responsible for the anti-inflammatory effects of $A$. azurea extracts (AMe and its AMe$\mathrm{Bu}$ fraction).

Nevertheless, the $n$-butanol extract of $A$. azurea and rosmarinic acid are good candidates for further investigation of their anti-inflammatory activity. In conclusion, our results support the traditional use of Anchusa species in treating inflammatory conditions and wounds.

\section{Acknowledgements}

The authors thank the Research Foundation of Hacettepe University (Grant No. 302301005), Turkey for financial support and Prof. Hayri Duman for identification of the plant.

of caffeoyl derivatives and other natural phenolic compounds: LDL protection against oxidation and decrease in the proinflammatory lysophosphatidylcholine production. J. Nat. Prod. 64, 480-486.

Chamberlain D. F. (1978), Anchusa L. In: Flora of Turkey and The East Aegean Islands (Davis P. H., ed.). Edinburgh University Press, Edinburgh pp. 388-402.

Dafni A., Yaniv Z., and Palevitch D. (1984), Ethnobotanical survey of medicinal-plants in Northern Israel. J. Ethnopharmacol. 10, 295-310.

Demirezer L. O. and Zeeck A. (2000), Chemical composition and biological activity of Anchusa leptophylla. J. Hacettepe Univ. Fac. Pharmacy 20, 7-17.

Disi A. M., Tamimi S. O., and Abuereish G. M. (1998), Effects of Anchusa strigosa root aqueous extract on gastric ethanol-induced ulcer in laboratory animals. J. Ethnopharmacol. 60, 189-198.

El Beyrouthy M., Arnold N., Delelis-Dusollier A., and Dupont F. (2009), Plants used as remedies antirheumatic and antineuralgic in the traditional medicine of Lebanon. J. Ethnopharmacol. 120, 315-334.

El S. N. and Karakaya S. (2004), Radical scavenging and iron-chelating activities of some greens used as traditional dishes in Mediterranean diet. Int. J. Food Sci. Nutr. 55, 67-74.

Erdemoglu N., Kusmenoglu S., and Vural M. (2004), $\gamma$-Linolenic acid content and fatty acid composition of Boraginaceae seed oils. Eur. J. Lipid Sci. Technol. 106, $160-164$.

Guil-Guerrero J. L., Maroto F. F. G., and Gimenez A. G. (2001), Fatty acid profiles from forty-nine plant 
species that are potential new sources of $\gamma$-linolenic acid. J. Am. Oil Chem. Soc. 78, 677-684.

Honda G., Yesilada E., Tabata M., Sezik E., Fujita T., Takeda Y., Takaishi Y., and Tanaka T. (1996), Traditional medicine in Turkey. 6. Folk medicine in West Anatolia: Afyon, Kutahya, Denizli, Mugla, Aydin provinces. J. Ethnopharmacol. 53, 75-87.

Kelley C. J., Harruff R. C., and Carmack M. (1976), Polyphenolic acids of Lithospermum-ruderale. 2. C-13 nuclear magnetic-resonance of lithospermic and rosmarinic acids. J. Org. Chem. 41, 449-455.

Kupeli E., Orhan I., and Yesilada E. (2007), Evaluation of some plants used in Turkish folk medicine for their anti-inflammatory and antinociceptive activities. Pharm. Biol. 45, 547-555.

Kuruuzum-Uz A., Guvenalp Z., Kazaz C., Salih B., and Demirezer L. O. (2010), Four new triterpenes from Anchusa azurea var. azurea. Helv. Chim. Acta 93, $457-465$.

Lardos A. (2006), The botanical materia medica of the Iatrosophikon - A collection of prescriptions from a monastery in Cyprus. J. Ethnopharmacol. 104, $387-406$.

Nader M. T., Abdual-baqi D. J., Al-Sarraj S. M., and Hussein W. A. (1986), The effect of different methods of extraction on the antimicrobial activity of medicinal plants. Fitoterapia LVII, 359-363.

Odabasoglu F., Cakir A., Suleyman H., Aslan A., Bayir Y., Halici M., and Kazaz C. (2006), Gastroprotective and antioxidant effects of usnic acid on indomethacin-induced gastric ulcer in rats. J. Ethnopharmacol. 103, 59-65.
Ramprasath V. R., Shanthi P., and Sachdanandam P. (2004), Anti-inflammatory effect of Semecarpus anacardium Linn. nut extract in acute and chronic inflammatory conditions. Biol. Pharm. Bull. 27, 2028-2031.

Sanbongi C., Takano H., Osakabe N., Sasa N., Natsume M., Yanagisawa R., Inoue K., Sadakane K., Ichinose T., and Yoshikawa T. (2004), Rosmarinic acid in perilla extract inhibits allergic inflammation induced by mite allergen, in a mouse model. Clin. Exp. Allergy 34, 971-977.

Suleyman H., Demirezer L. O., Kuruuzum A., Banoglu Z. N., Gocer F., Ozbakir G., and Gepdiremen A. (1999), Antiinflammatory effect of the aqueous extract from Rumex patientia L. roots. J. Ethnopharmacol. 65, 141-148.

Suleyman H., Cadirci E., Albayrak A., and Halici Z. (2008), Nimesulide is a selective COX-2 inhibitory, atypical non-steroidal antiinflammatory drug. Curr. Med. Chem. 15, 278-283.

Winter C. A., Risley E. A., and Nuss G. W. (1962), Carrageenan-induced edema in hind paw of the rat as an assay for anti-inflammatory drugs. Proc. Soc. Exp. Biol. Med. 111, 544-547.

Yesilada E., Honda G., Sezik E., Tabata M., Fujita T., Tanaka T., Takeda Y., and Takaishi Y. (1995), Traditional medicine in Turkey. 5. Folk medicine in the Inner Taurus Mountains. J. Ethnopharmacol. 46, $133-152$.

Youn J., Lee K. H., Won J., Huh S. J., Yun H. S., Cho W. G., and Paik D. J. (2003), Beneficial effects of rosmarinic acid on suppression of collagen induced arthritis. J. Rheumatol. 30, 1203-1207. 